\title{
Filtered tailings in Western Australian iron ore projects - comparison of filtered tailings with other tailings disposal methods
}

\author{
C.S. Hogg Coffey Mining, Australia
}

\begin{abstract}
The opportunity to utilise innovative techniques to improve mining project outcomes is now more favourably viewed when conducting feasibility studies. One option that has been studied is the use of filtered tailings with the tailings being disposed in an integrated waste landform, i.e. allowing a form of co-disposal. The tailings are de-watered using a filter system and delivered to the tailings storage site via a truck operation or utilising conveyor systems. De-watering the tailings in the plant to produce filtered tailings, at around 80\% solids, reduces water consumption for the project. Another advantage of filtered tailings is the placement of tailings at higher density allowing smaller disposal footprint areas when compared with more traditional options. This paper presents a case study including financial analyses and compares filtered tailings and thickened tailings options. One of the main aspects investigated by this paper is water conservation and the cost of water.
\end{abstract}

\section{Introduction}

Traditionally, tailings disposal from beneficiation type processes utilised in Iron Ore mining use slurry systems. The tailings, mostly comprising silts and clays, are usually deposited in valley type tailings storages as the terrain adjacent to many iron ore mines lends itself to this type of tailings storage design. These types of facilities have been successfully used since the 1980s. However, one of the main disadvantages of these types of facilities is the requirement for large water resources as the tailings are typically pumped to the facilities at around $40 \%$ solids.

More recently, in-pit tailings disposal has been utilised at some mine sites. This design concept utilises mined out pits, enabling tailings disposal to be performed in areas that have already been disturbed leading to better environmental outcomes. Typically the tailings are pumped to the storage facilities at slurry densities similar to above ground facilities. In-pit facilities have typically allowed greater water return to the plant, hence improving water management. Closure of in-pit tailings storages has similar constraints to above ground valley storages, all be it with a reduced final tailings surface area.

The opportunity to utilise innovative techniques to improve mining projects outcomes is now more favourably viewed when conducting feasibility studies. One option that has been studied is the use of filtered tailings with the tailings being disposed in an integrated waste landform, i.e. allowing a form of co-disposal. The tailings are de-watered using a filter press and delivered to the tailings storage site via a truck operation or utilising conveyor systems. De-watering the tailings in the plant to produce filtered tailings, at around $80 \%$ solids, reduces water consumption for the project.

While filtered tailings option presents a higher operational/business risk than more conventional thickened tailings option (approximately 60\% solids) where technology has a proven track record, the additional risk can be offset with the opportunity that the filter tailings option presents for water savings. Analyses indicate a potential reduction in project water requirements for filtered tailings of approximately $40 \%$ when compared with a thickened tailings option (62\% solids) and even greater when compared with conventional slurry at $40 \%$ solids.

Another advantage of a filtered tailings option is that the tailings are more easily handled as a solid and as a consequence, the placement of the tailings at higher density allows for a smaller footprint area when compared with more traditional options. The closure of such facilities should be less problematic as time dependent consolidation of the tailings deposit is minimal. Rehabilitation can potentially be performed progressively with final capping performed close to decommissioning of the plant. 


\section{Terminology}

The following are adopted terminologies relating to tailings disposal/storage:

- Filter cake: tailings dewatered utilising a filter technology to a moisture content of about $20 \%$ or less (Access Mining Consultants Ltd, 2003).

- Dry stacking: the description of the overall process of transporting, placing, and compacting filtered tailings to form a unsaturated tailings stack. Dry stacking/dry stack tailings has found wide spread use in referring to filter tailings (Access Mining Consultants Ltd, 2003).

- Slurry tailings: traditional tailings disposal using pumping and pipelines.

- Thickened tailings: tailings of a higher density but still amenable to being pumped. Thickened tailings tend to be non segregating, with a typical \% solids in the range of 50 to $65 \%$ depending on the tailings rheology (Condon and Lear, 2006).

- Paste: highly thickened tailings more typically utilised for underground backfill operations.

- Integrated waste landform (IWL): a tailings storage facility (TSF) that is located inside the waste rock storage (Lane, 2007).

\section{Literature review}

Dry stacked tailings have been used on a small number of sites around the world. A literature search revealed that the following are some sites which are using dry stacked tailings:

- Pogo Gold Project, Alaska

- Raglan Mine, Canada

- Greens Creek Mine (base metals project), Alaska

- La Coipa Gold Project, Chile

- Skorpion Zinc Project, Namibia.

The benefits (Access Mining Consultants Ltd, 2003) of dry stacking tailings can be summarised as follows:

- Water conservation in arid environments where either water supply is scarce and/or expensive to procure.

- Tailings are more easily handled in cold regions. Project water management in winter freezing conditions is easier as return water is not being relied upon.

- Recovery of metals from solution through the filtration process prior to stacking.

- Recovery of process chemicals from solution through the filtration process prior to stacking.

- Dry stacks are essentially immune to catastrophic failure and can be designed to withstand static and seismic forces.

- The footprint is smaller, when compared to other forms of tailings storage, because of the low moisture content and higher density of the stacked tailings.

- There is limited leachate production because the volume of moisture incorporated within the tailings is small.

- Allows progressive covering and rehabilitation for closure.

- Use of dry stacked tailings is seen as good environmental stewardship.

The following table summarises characteristics of some existing dry stacking operations based on a literature review (Condon and Lear, 2006; Copeland and van Greunen, 2006; Minson and Herrera, 2004). 
Table 1 Existing dry stacking operations

\begin{tabular}{|c|c|c|c|c|c|c|}
\hline Site & $\begin{array}{l}\text { Type of } \\
\text { Tailings }\end{array}$ & $\begin{array}{l}\text { Filter } \\
\text { Technology }\end{array}$ & $\begin{array}{l}\text { Construction of } \\
\text { Stack }\end{array}$ & $\begin{array}{l}\text { Design } \\
\text { Moisture } \\
\text { Content }\end{array}$ & $\begin{array}{l}\text { Liner } \\
\text { Type }\end{array}$ & $\begin{array}{l}\text { Underdrain/ } \\
\text { Internal } \\
\text { Drainage }\end{array}$ \\
\hline $\begin{array}{l}\text { Greens Ck, } \\
\text { Alaska }\end{array}$ & $\begin{array}{l}\text { Polymetal } \\
\text { underground } \\
\text { tailings }\end{array}$ & $\begin{array}{l}\text { Filter press, } \\
750 \text { t/day to } \\
\text { stack }\end{array}$ & $\begin{array}{l}40 \text { t trucks, spread } \\
\text { by dozer, } \\
\text { compaction with } \\
\text { vibratory roller }\end{array}$ & $\begin{array}{l}12-16 \% \text { at } \\
90 \% \text { std } \\
\text { proctor }\end{array}$ & $\begin{array}{l}\text { HDPE } \\
\text { /clay }\end{array}$ & Yes \\
\hline $\begin{array}{l}\text { Skorpion, } \\
\text { Namibia }\end{array}$ & $\begin{array}{l}\text { Fine grained } \\
\text { with } 13 \% \\
\text { clay }\end{array}$ & $\begin{array}{l}\text { Belt filter, } \\
4,080 \text { t/day }\end{array}$ & $\begin{array}{l}\text { Conveyor stacker } \\
\text { system }\end{array}$ & $40 \%$ & $?$ & $?$ \\
\hline $\begin{array}{l}\text { La Copa, } \\
\text { Chile }\end{array}$ & Gold tailings & Belt filter & $\begin{array}{l}\text { Conveyor stacker } \\
\text { system }\end{array}$ & $\begin{array}{l}21 \% \text { at plant, } \\
13 \% \text { at dam }\end{array}$ & $?$ & $?$ \\
\hline
\end{tabular}

Possible issues with dry stacking:

- In periods of heavy rainfall it may be difficult to maintain access to the stack.

- Management of runoff from the stack and erosion of stack may require rock protection on outer slopes and rip-rap/liners drainage channels.

- Dust generation can be a problem particularly in arid environments (also under freezing conditions) (Condon and Lear, 2006).

- Significant clay content:

- Difficult to continuously operate equipment at design moisture content. Excellent understanding of the moisture expected to be handled is required to ensure expected variability is designed into the equipment. Good plant management is essential.

- If the conveyor systems experience difficulties, i.e. conveyor stops, plant stops.

○ Slumping of stack may be problematic. High waste rock walls required to contain stack toe.

\section{$4 \quad$ Case studies}

During the research of the dry stacked tailings concept, Coffey Mining was unable to find any site where tailings are being dry stacked either together with or surrounded by mine waste. In addition to the benefits outlined above, the advantages of dry stacked tailings within mine waste to form an IWL are:

- Encapsulation of potential acid generating materials, both mine waste and tailings, within one structure.

- Lower longer term liability of the IWL compared to conventional above ground TSFs.

- Ability to co-dispose of waste materials within one structure.

Two case studies are presented. The studies were scoping/pre-feasibility level studies into the use of dry stacking of filtered tailings for recent magnetite projects in the north west of Western Australia. The designs were not developed past an initial assessment stage and more traditional methods of tailings disposal were adopted for subsequent feasibility studies and for project approvals. At present, it is understood that the projects have not progressed past the feasibility stage. This paper seeks to further develop, assessments performed during these studies in order to further research the dry stacking concept as it could be applied to a project in the semi arid/arid areas of Western Australia and elsewhere.

\subsection{Case 1}

In this case study, two concepts for tailings storage for a Magnetite project in Western Australia was assessed (Coffey Mining, 2008). 
The tailings to be stored comprised neutral tailings of limited buffering capacity (Total S, 1.6\%) and enriched in metals such as Arsenic. The tailings were non plastic with $78 \%$ passing the 75 micron sieve size. The study examined a filtered tailings option with $78 \%$ solids and a thickened tailings option with $62 \%$ solids.

Figure 1 shows a dry density and moisture content relationship for tailings with a specific gravity (SG) of the solids of 3.3. This curve was utilised in assessment of the design dry density and moisture content for deposited tailings. Please note that the curve is generic and represents a 'zero' air voids curve. In the case of filtered tailings, once placed a 'wet' filter cake would dry back to an unsaturated moisture content and a higher dry density. Thickened tailings following deposition would settle from an initial dry density at the point of deposition to a greater settled dry density within the tailings storage facility following release of water from the tailings and consolidation processes.

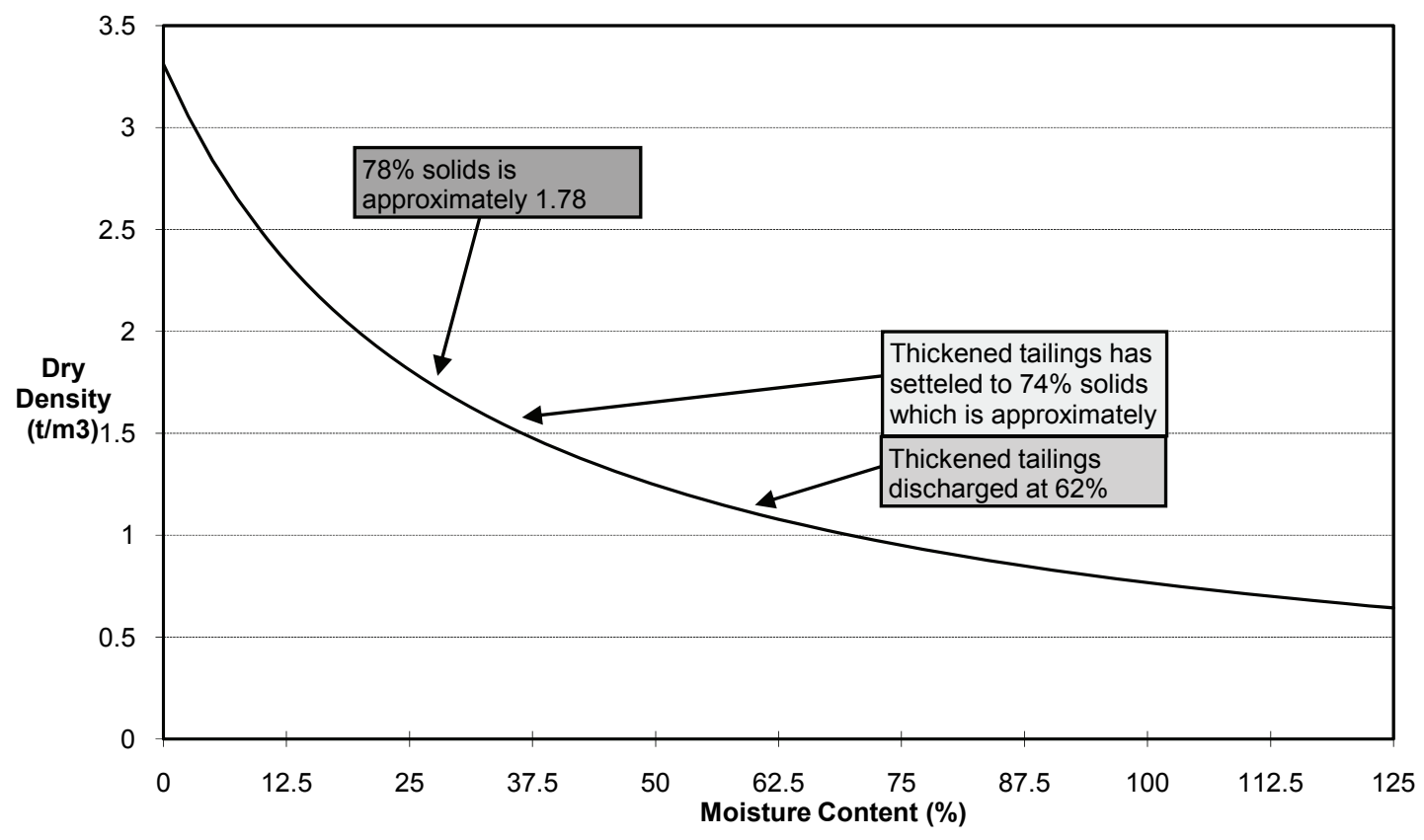

Figure 1 Tailings dry density versus moisture content (Coffey Mining, 2008)

As part of the study, the two tailings storage options assessed comprised:

- Thickened tailings option: two (2) paddock cells comprising starter embankments constructed from mine waste. The embankments were to be raised utilising upstream methods and mine waste. Central decants with a dedicated water recovery pump.

- Dry stacking within an IWL: a three (3) cell IWL.

The main driver for undertaking this options study was to examine whether the use of filtered tailings/dry stacking could be feasible based on cost savings from reduced water use. Producing a filtered tailings product with $78 \%$ solids would reduce project water consumption.

The IWL is constructed using mine waste sourced directly from open pit operations to form cells. The tailings will be deposited into the IWL cells using a conveyor stacker operation. More details on the likely operation of the IWL are presented in the Case 2 discussion.

Details of the IWL and paddock storage concept designs are summarised in Table 2 and a general arrangement is presented in Figure 2. 
Table 2 Concept design - summary (Coffey Mining, 2008)

\begin{tabular}{|c|c|c|}
\hline & Paddock Option & IWL \\
\hline Production & 4 Mtpa for 15 years & 4 Mtpa for 15 years \\
\hline Final external footprint 3 Cells (ha) & 232 & 174 \\
\hline $\begin{array}{l}\text { Final average embankment height } \\
\text { (aver)m) }\end{array}$ & 21 & 40 \\
\hline $\begin{array}{l}\text { Outer embankment slope (V:H - } \\
\text { degrees) }\end{array}$ & $1: 2.75-20^{\circ}$ & $\begin{array}{l}\text { Concave varies from } 15^{\circ} \text { at toe } \\
\text { level to } 35^{\circ} \text { at the top level }\end{array}$ \\
\hline Supernatant water recovery & Central decant & \\
\hline Underdrainage system & Upstream perimeter drain & $\begin{array}{l}\text { Basal and upstream perimeter } \\
\text { drain }\end{array}$ \\
\hline Tailings density & $1.65 \mathrm{t} / \mathrm{m}^{3}$ & 1.90 t/m³ (Solids SG 3.31) \\
\hline Moisture content & - & $15 \%$ \\
\hline Total tailings storage volume $\left(\mathrm{M} \mathrm{m}^{3}\right)$ & 36.2 & 26.7 \\
\hline
\end{tabular}

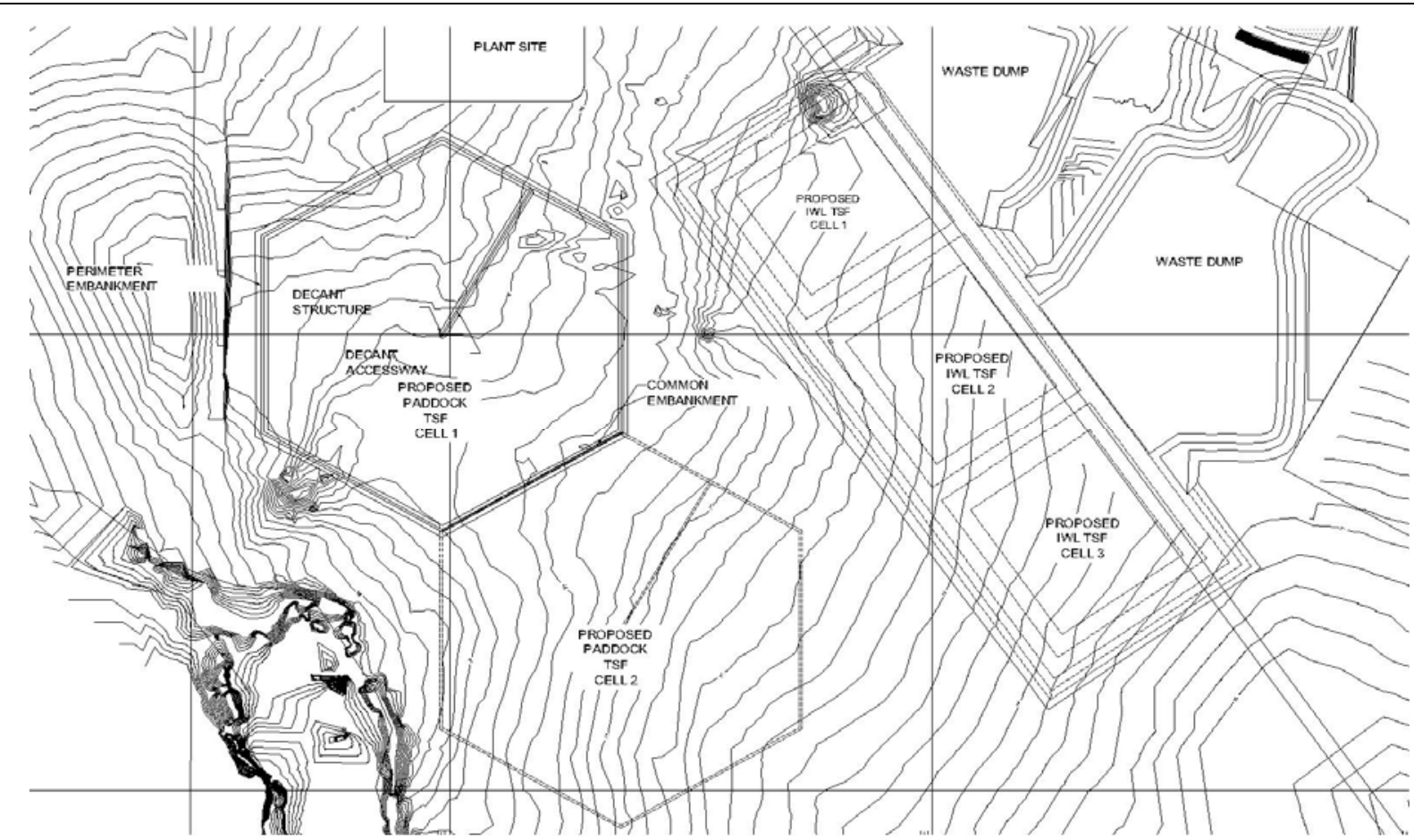

Figure 2 Case 1 general arrangement (Coffey Mining, 2008)

\subsection{Other cases}

The concept of dry stacking within an IWL was also examined for another magnetite project in Western Australia. The main driver for adoption of dry stacking in this case was a constrained site, with a restricted area available for development of a conventional tailings storage facility. No comparison of options was performed as part of the original study, however, an operational concept was developed. The option for the waste storage facility comprises one structure, constructed from mine waste, which is co-disposed with filtered, dry stacked tailings, to form an IWL.

In this case, initial construction of the IWL would comprise construction of zoned starter embankments for the cells using compacted sandy clay/clayey sand for the upstream zone, placement of oxidised mine waste as a transition material, and placement of fresh mine waste on the downstream batter. These materials are to 
be sourced from an initial pre-strip operation and borrow areas. The IWL would be raised progressively by mine waste placement around the tailings storage, utilising waste dump construction techniques, over the life of the project.

The IWL would be operated as follows:

- During the initial deposition, tailings will be placed in layers and covered with mine waste dumped from trucks.

- Once the moisture content of the filtered tailings is optimised, at or below $15 \%$, the tailings mix (coarse and fine tailings) would be progressively placed in layers up to $3 \mathrm{~m}$ thick and allowed to dry sufficiently before being covered with a $0.5 \mathrm{~m}$ thick layer of mine waste to prevent dust formation and provide a surface for heavy equipment to traffic.

- Mine waste is then progressively placed on the tailings as each lift is constructed.

- The sequential placement of tailings and mine waste proceeds to form a series of layers to the final design height at the end of the mining operation.

- Mine waste is progressively placed around the outer perimeter embankment and internal embankments as each lift is constructed to the final design height throughout the mining operation.

- The downstream batter slopes can be rehabilitated as soon as possible after the mine waste is placed.

\section{$5 \quad$ Further analysis}

\subsection{Water management}

The water management implications of the options were assessed by examining the tailings storage water balance analyses for the thickened tailings option utilising a spreadsheet which calculates the inflows (i.e. slurry water, rainfall run off) and outflows (i.e. evaporation from tailings beaches and ponds, evapotranspiration from tailings, seepage and water retention within the tailings) from the system. For the dry stacking option the water usage was estimated based on the design percentage solids of the filter cake produced at the plant, that is water is recovered at the plant and the water usage is based on the percentage solids/moisture content of the filtered tailings leaving the plant.

Table 3 summarises the water usage for various options for Case 1.

Table 3 Water management - summary

\begin{tabular}{ll}
\hline & Case 1 \\
\hline Production & 4 Mtpa for 15 years \\
Potential water return - filter tailings & NA \\
Potential water return - thickened tailings & $20 \%$ (average)* \\
Approximate water requirements $\mathrm{m}^{3} / \mathrm{t}$ (of tailings) dry stacking & 0.28 \\
$\begin{array}{l}\text { Approximate water requirements } \mathrm{m}^{3} / \mathrm{t} \text { (of tailings) thickened } \\
\text { Water saving }\end{array}$ & 0.48 \\
\hline $\begin{array}{l}\text { Note: * as a } \% \text { of slurry water inflow. } \\
\text { Inflows: Rainfall runoff, } 4 \% \text { and slurry water inflow. }\end{array}$ & \\
Outflows: Evaporation and evapo-transpiration $17 \%$, seepage 13\%, water retention $50 \%$. water return 20\%.
\end{tabular}

Based on the analyses carried out, the use of dry stacking of filtered tailings has the potential to reduce project water requirements by approximately $40 \%$. It has been assessed that, the second case also has the potential for similar reductions in project water requirements.

Valley type tailings storages at haematite operations utilising conventional slurry systems ( $35-40 \%$ solids) in north west Western Australia typically have water returns of 10 to $20 \%$ of slurry water inflow, however, water return from these tailings storages is usually less of a priority due to excess water from mine de- 
watering. Storages at these operations also tend to have relatively large surface areas. The water usage for these types of systems is approximately $1.3-1.5 \mathrm{~m}^{3} / \mathrm{t}$ of tailings.

\subsection{Closure}

Adoption of the dry stacking option would result in a reduced rehabilitation area (about half of that required for the thickened tailings option, i.e. for Case 1). This reduction in area and the conceptual capping design has been utilised in the cost analyses presented in Section 5.3.

The capping system proposed in the preliminary design and considered appropriate at the conceptual design stage due to a preliminary geochemical characterisation (refer Section 4.1), comprises the following:

- A $0.5 \mathrm{~m}$ thick capillary break layer to limit the potential for acid and soluble metals/salts from the tailings to move by capillary action into the overlying cover and impact vegetation growth. Detailed design, when characteristics of the production tailings and potential cover materials are better defined, may show that this capillary break zone is not required. The requirement for a capillary break layer is more likely to be required for a thickened tailings/slurry tailings option than for a dry stacking option.

- A $0.5 \mathrm{~m}$ thick compacted soil layer which is intended to remain relatively saturated and assist in limiting water infiltration and oxygen ingress into the TSF. The material for this layer would probably be selecting fine waste rock material which is moisture conditioned and compacted.

- A $1.5 \mathrm{~m}$ protection layer to protect the compacted layer from evapo-transpiration impacts such as drying and cracking, animal activity, or penetration of roots. The protection layer is the primary moisture 'store and release' element of the cover system, and provides a layer for root growth. This layer would comprise loosely placed mine waste suitable for the growth of vegetation.

- A $0.1 \mathrm{~m}$ thick growth layer, to provide a zone for vegetation germination, which could include 'rock mulch' or scavenged topsoil.

The cover system costed as part of a closure cost for the TSF was assumed to be nominally $2.5 \mathrm{~m}$ thick.

\subsection{Cost comparison}

In order to compare the cost of each option the work performed for the scoping study for Case 1 was extended by conducting a net present cost analysis with two different discount rates. The costs utilised in the earthworks and closure aspects were based on rates for similar projects in Western Australia. Other costs were estimated by referencing literature which provides typical values of operating costs, filter and thickener equipment costs etc. The cost of water was utilised as a project variable and a minimum rate of US\$1/m was used (based on advice during the study). Table 4 summarises the cost/rates used in the cost analyses and Table 5 summarises the net present cost from the Case 1 analyses. The estimates exclude the cost of delivery systems, i.e. conveyors and pipework.

It should be noted that the base cost of $\$ 1.25 / \mathrm{m}^{3}$ (US\$ $1 / \mathrm{m}^{3}$ ) for water is based on the cost of pipelines and pumps (CAPEX and OPEX) and also the fact that the concentrate from the mine is pumped to a port for shipping. It is not a purchase price for water.

Table 4 Costs estimates and rates utilised in cost analysis

\begin{tabular}{lll}
\hline & Filtered Tailings & Thickened Tailings \\
\hline Initial capital & $\$ 13.6 \mathrm{M}$ & $\$ 19.2 \mathrm{M}$ \\
OPEX & $\$ 2.25 / \mathrm{t}$ & $\$ 1.5 / \mathrm{t}$ \\
Closure & $\$ 250,000 / \mathrm{ha}$ & $\$ 250,000 / \mathrm{ha}$ \\
\hline
\end{tabular}

Note: Amounts in millions of US\$.

Estimates above exclude delivery systems i.e. conveyors and pipe work.

Exchange rate AU $\$ 1=\mathrm{US} \$ 0.80$. 
Table 5 Cost analysis - summary

\begin{tabular}{lllll}
\hline Cost of Water & $\begin{array}{l}\text { Dry Stacking } \\
\text { NPC (US\$) }\end{array}$ & $\begin{array}{l}\text { Thickened } \\
\text { Tailings NPC } \\
\text { (US\$) }\end{array}$ & $\begin{array}{l}\text { Difference in } \\
\text { NPC(US\$) 5\% } \\
\text { Discount Rate }\end{array}$ & $\begin{array}{l}\text { Difference in } \\
\text { NPC(US\$) 10\% } \\
\text { Discount Rate }\end{array}$ \\
\hline US\$ $1 / \mathrm{m}^{3}$ & $85 \mathrm{M}-119 \mathrm{M}$ & $77 \mathrm{M}-108 \mathrm{M}$ & $11.4 \mathrm{M}$ & $7.9 \mathrm{M}$ \\
$\mathrm{US} \$ 2.5 / \mathrm{m}^{3}$ & $97 \mathrm{M}-136 \mathrm{M}$ & $97 \mathrm{M}-137 \mathrm{M}$ & $-1.0 \mathrm{M}$ & $-0.8 \mathrm{M}$ \\
\hline
\end{tabular}

Note: Exchange rate AU\$1 = US\$ 0.80 .

Based on the analyses, the use of dry stacking is more expensive than a thickened tailings option when the cost of water is US\$ $1 / \mathrm{m}^{3}$. A tornado graph in Figure 3, examines the sensitivity of varying selected costs for the base case on the NPC of the two options. The costs that were varied were the cost of water, an over-run in operating costs, an over-run in capital costs and the effect of removing closure provisions. As can be seen from the graph an increase in the cost of water is potentially the main area where filtered tailings would become cost competitive with thickened tailings. This sensitivity is further examined in the proceeding figures.

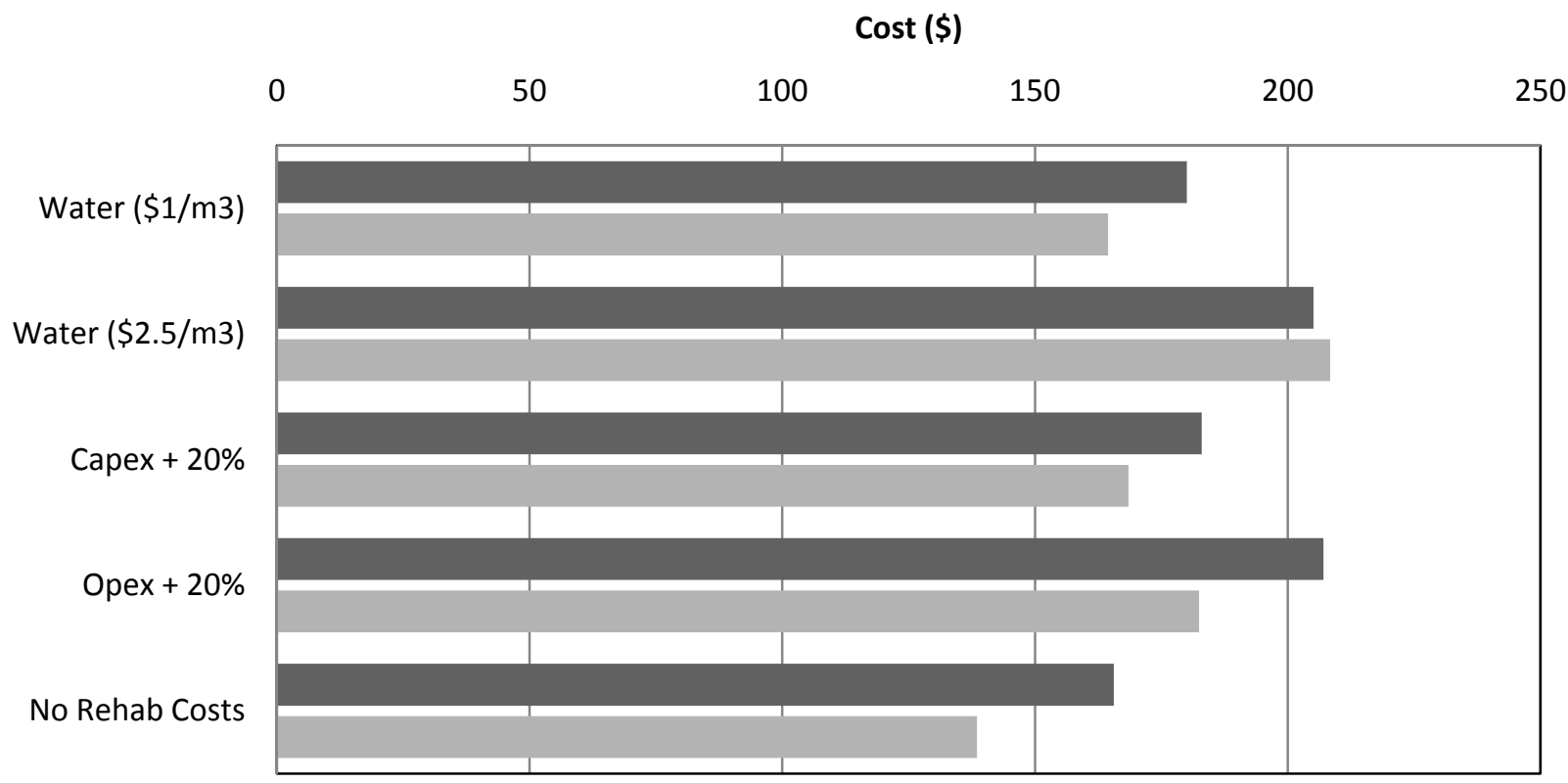

Filter Tailings Option (78\% solids) - Thickened Tailings Option (62\% solids)

Note: No discount rate applied

Figure 3 Tornado graph - sensitivity of option ranking to various scenarios

NPC analyses were conducted in order to assess the cost of water that would make the dry stacking option cost competitive. The results of theses analyses are presented in Figure 4. 


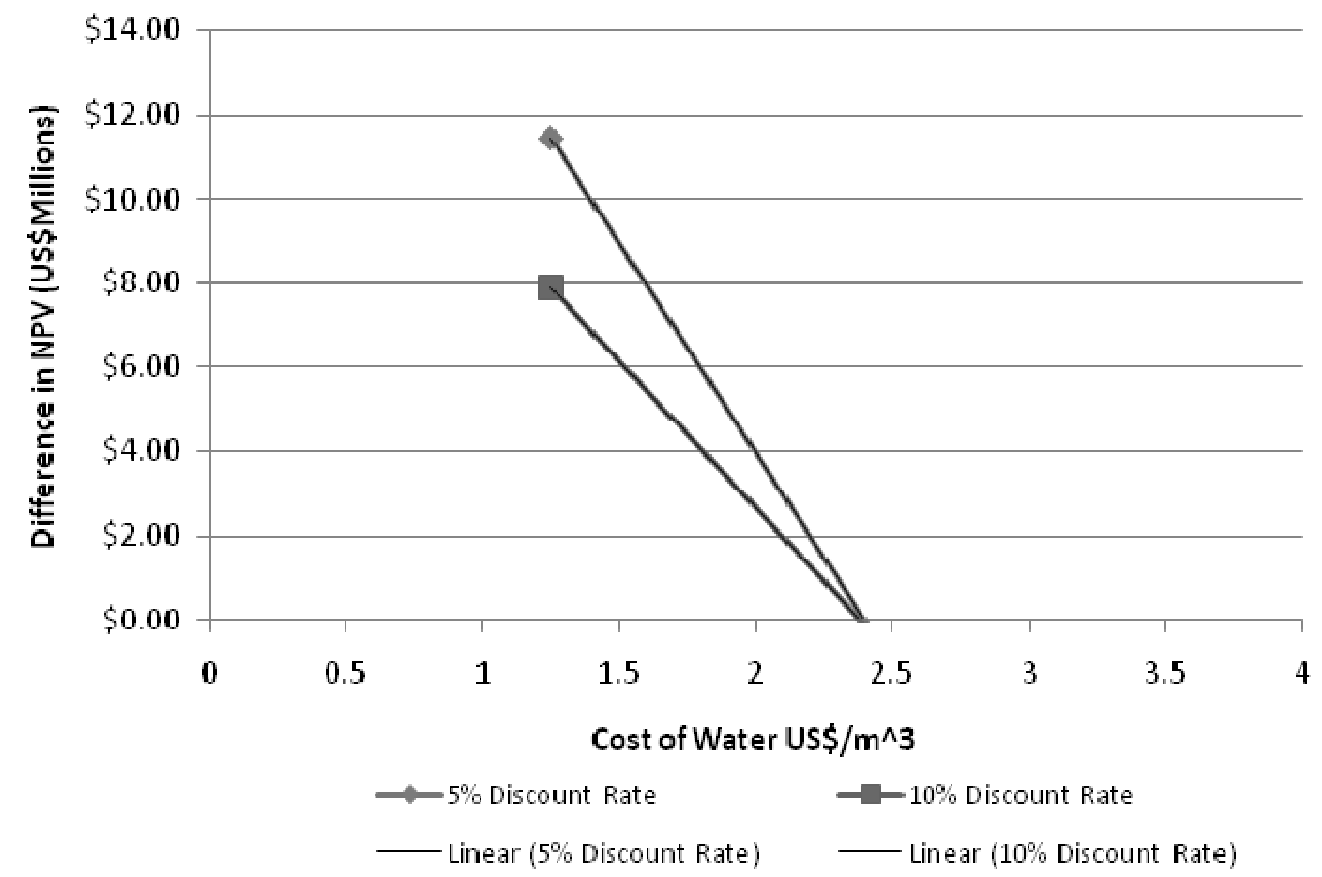

\section{Figure 4 NPC analyses results}

Additional sensitivity analyses were performed by adopting lower water return efficiency for a thickened tailings option (i.e. water return of $10 \%$ of slurry water inflow). The results from this sensitivity assessment are provided in Figure 5.

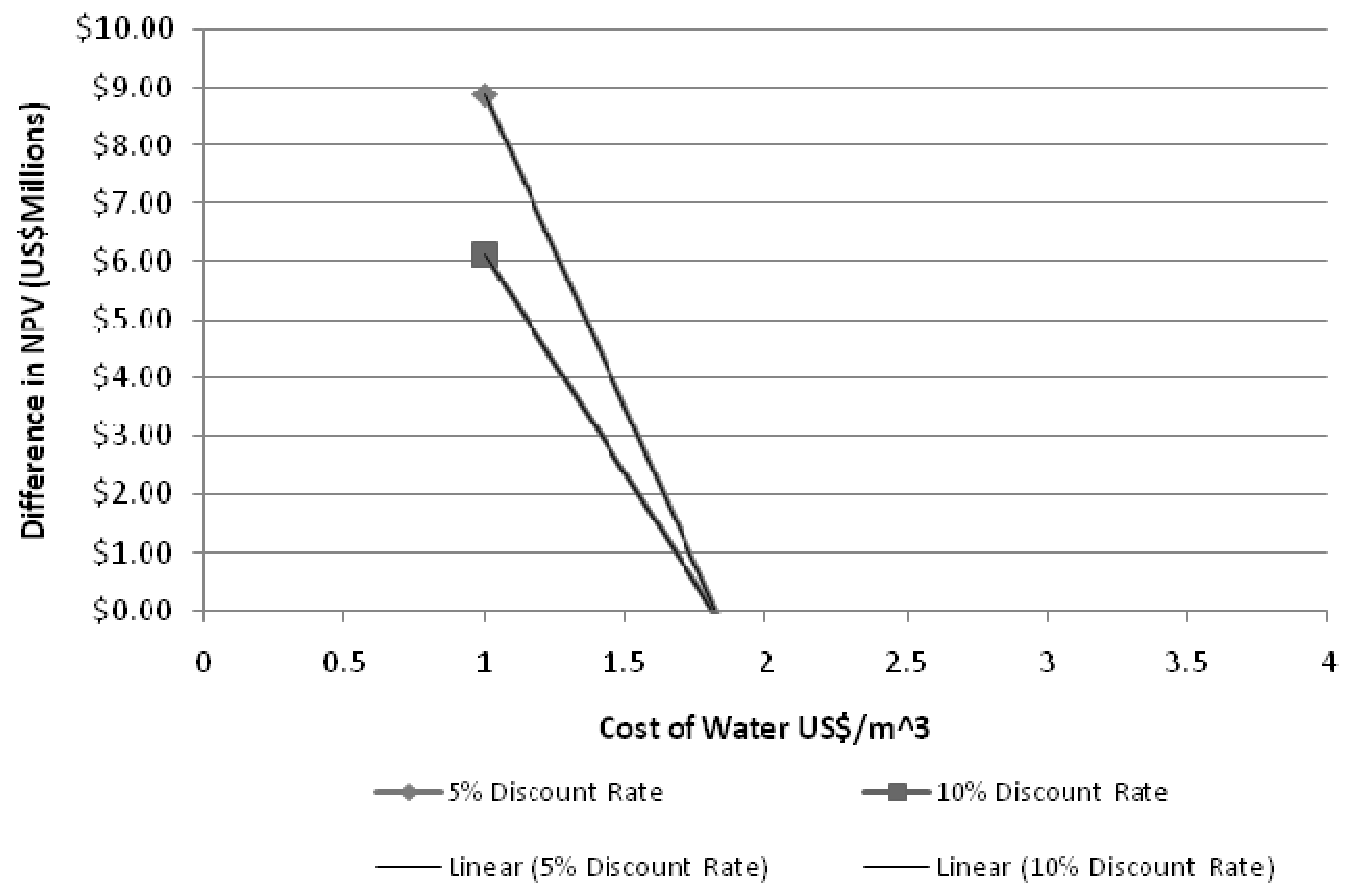

Figure 5 NPC analyses results $-10 \%$ water return

The results of the NPC analysis for Case 1 concept indicate that a 'break even' point where a dry stacking option would start to become attractive purely from a cost point of view is for a water cost of approximately US\$ $2 / \mathrm{m}^{3}-2.5 / \mathrm{m}^{3}$. 


\section{Conclusions}

Based on the analyses presented in this paper, it does not appear that dry stacking of tailings is an economical form of tailings disposal for the magnetite iron projects in the North West of Western Australia. However, it has been concluded that dry stacking is to be seriously considered as a tailings disposal option where the mining project is constrained by available land, and/or where there is a lack of available water resources or such resources are expensive. Other occasions where this option may be favourable are where terrain or borrow/fill sources make construction of conventional tailings disposal facilities expensive.

It should, however, be noted that pressure is being increasingly applied to the user of water resources in Australia and the current system where the user pays 'virtually no rent' for the water in remote areas may not continue in the future. In future, water which is not currently factored into project analyses may well change the project economics in favour of filtered tailings for iron ore projects in Western Australia.

\section{Acknowledgements}

I wish to acknowledge the mentoring and proof reading of this paper by Christopher Lane, senior principal, Coffey Mining and project manager for the two original studies.

\section{References}

Access Mining Consultants Ltd (2003) Examination of Revegetation Methodologies for Dry Stack Tailings in Northern Environments, Mining Environmental Research Group, Government of Yukon, pp. 3-4.

Coffey Mining (2008) Balla Balla Magnetite Project, Conceptual Design of Tailings Storage Facility, Coffey Mining Report.

Condon, P. and Lear, K. (2006) Geochemical and Geotechnical Characteristics of Filter-Pressed Tailings at The Greens Creek Mine Admiralty Island, Alaska, in Proceedings 7th International Conference on Acid Rock Drainage, March 26-30, 2006, St Louis, USA, pp. 350-363.

Copeland, A. and van Greunen, P. (2006) Disposal of Belt Filtered Tailings - Skorpion Zinc Case Study: Feasibility, Design and Early Operation, Australian Centre for Geomechanics, Perth, Australia, pp. 243-254.

Lane, J.C. (2007) Case histories of integrated waste landforms and in-pit deposition; what are the costs of these options?, Total Tailings Management Seminar Notes, Section 10, December 5-7, 2007, Perth Western Australia, Australian Centre for Geomechanics, Perth, Australia, $14 \mathrm{p}$.

Minson, D.N. and Herrera, R. (2004) Filtering Systems for Dry Tailings Deposition, Solid - Liquid Separation 04, November 8-9, 2004, Cape Town, South Africa, Minerals Engineering International, 14 p. 